\title{
Causes and consequences of a construction disaster in a historic church
}

\author{
Lukasz Bednarz ${ }^{1, *}$, and Piotr Opalka ${ }^{2}$ \\ ${ }^{1}$ Wroclaw University of Science and Technology, Faculty of Civil Engineering, Wybrzeze \\ Wyspianskiego 27, 50-370 Wroclaw, Poland \\ ${ }^{2}$ University of Applied Sciences in Nysa, Institute of Technical Sciences, ul. Obroncow Tobruku 5, \\ 48-300 Nysa, Poland
}

\begin{abstract}
Paper concerns a construction disaster, which took place on June 4, 2018 in the $14^{\text {th }}$ century St. George church in Hajduki Nyskie (Opole Voivodeship). The object is famous for its well-preserved $15^{\text {th }}$ century wall polychromes. During the construction works, the eastern gable wall, part of the barrel vault with lunettes and part of the orchid roof truss collapsed at the roof truss. Some elements of the equipment were also destroyed. As a result of the catastrophe, valuable wall polychromes were directly threatened. Paper presents the causes and consequences of the catastrophe.
\end{abstract}

\section{Objects description and history}

Hajduki Nyskie village (German: Heidau), is located approx. $6 \mathrm{~km}$ south of Nysa (Opole Voivodeship). The first mention of the church of St. George (Fig. 1), [1] comes from around 1305. Until 1502, he served as a parish church, and in later years as a filial church it was assigned to the parish in neighboring Kepnica. The object was erected in the central point of the village on a small hill (about $190 \mathrm{~m}$ above the sea level), at the edge of the riverside route. The church is oriented, made of stone, one nave, with a bell tower and presbytery built in the 15 th century from the front. During the fifteenth century, in three stages in the interior of the church, wall paintings were preserved, mostly to this day (Fig. 2). The structural arrangement of the mono structural church, characteristic of medieval sacred buildings, in which all the main structural elements were made of materials with similar physicochemical characteristics, i.e. made of brick, as well as quarry and field stone.

In the Baroque period, at the turn of the seventeenth/ eighteenth century, during a thorough reconstruction, a barrel vault with six lunettes was established above the nave. The buttresses were built in places of Romanesque lizens. The Baroque vaults irreversibly destroyed some of the valuable Gothic polychromy on the inner walls of the nave, and the choir and organ prospect destroyed most of the polychromy on the western wall. At the end of the nineteenth century, the temple was renovated in the Neo-Gothic spirit, partly obliterating the Romanesque and Gothic style features, [2]. The St. George church in

\footnotetext{
${ }^{*}$ Corresponding author: lukasz.bednarz@pwr.edu.pl
} 
Hajduki Nyskie on the basis of the decision of May 30, 1964, entered into the register of monuments of the Opole Voivodeship under register no. 919/64.
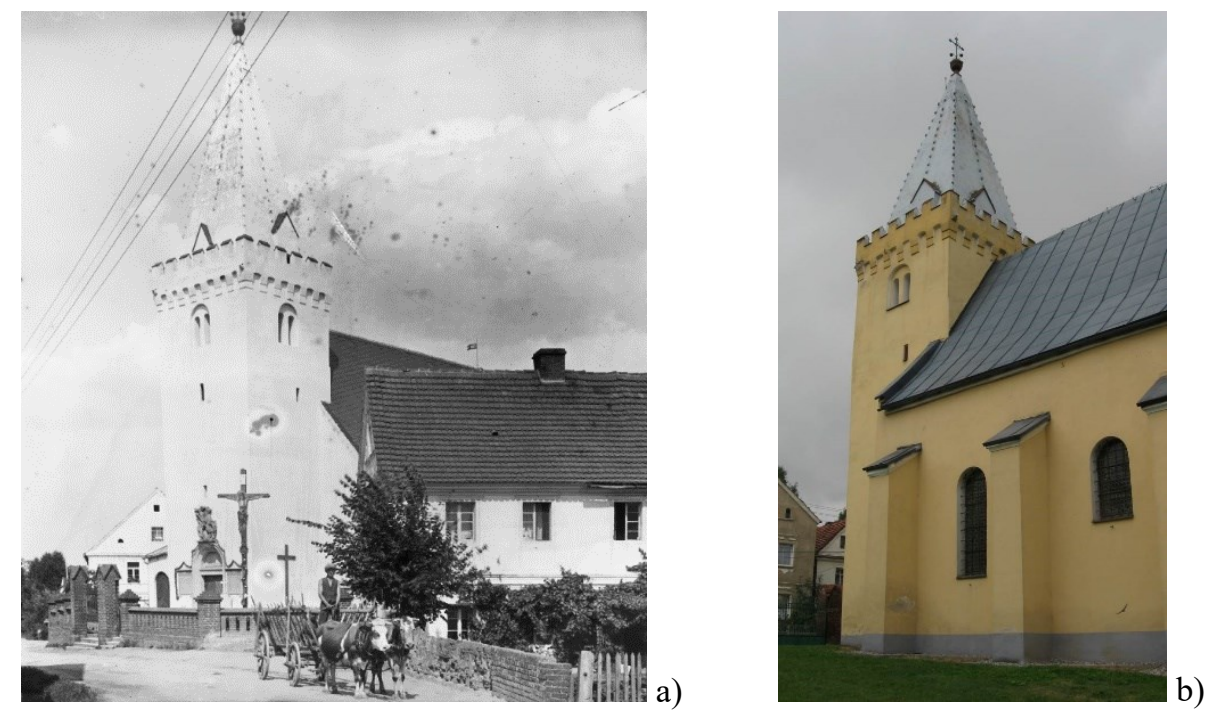

Fig. 1. Church of St. George: a) in the years 1910-1920 [1], b) in 2014.

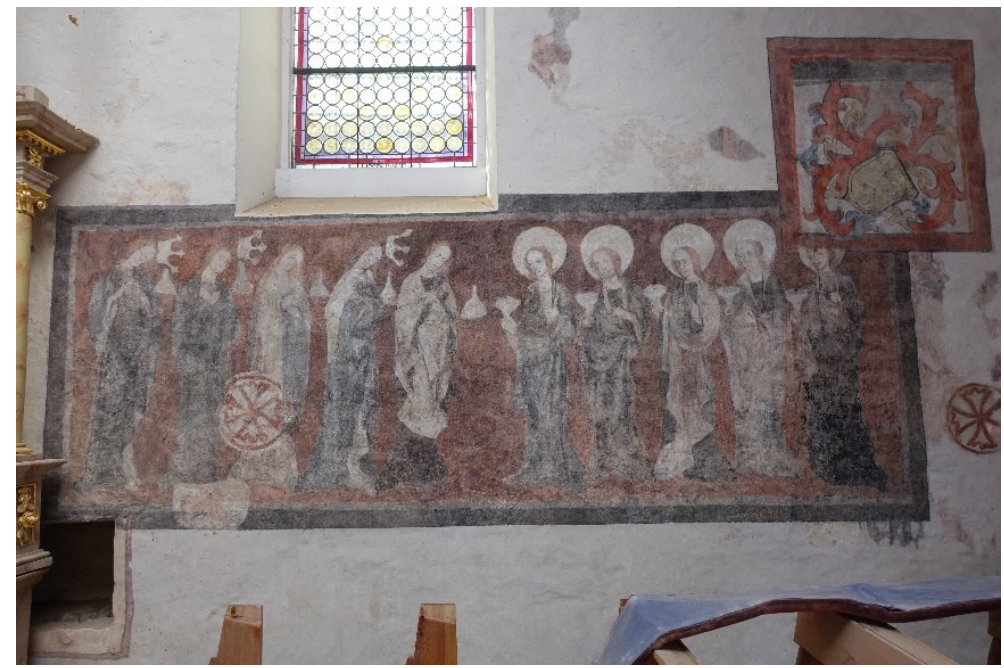

Fig. 2. Wall polychrome inside the church from the 15 th century.

The body of the nave was erected on a plan similar to a rectangle, in the proportions of about 1: 2 - with a width of $10.57 \mathrm{~m}$ from the west side up to $10.71 \mathrm{~m}$ from the east and a length of about $17.85 \mathrm{~m}$. The interior has a variable width, from $8.57 \mathrm{~m}$ to $8.66 \mathrm{~m}$, and length $15.64 \mathrm{~m}$. The nave built on the south side of the main nave have the task of reducing the forces generated by the barrel vault. Northern shear stiffness is provided by approx. $2 / 3$ of the length of the nave, so-called "Old sacristy."

External walls are about $100 \mathrm{~cm}$ thick. The windows in the outer walls correspond to the telescope system.

The walls above the vaults were carelessly made of solid brick with a thickness of about $70 \mathrm{~cm}$. From the inside, they are not plaster. Only about half of the northern wall above the vaults has been preserved as a stone wall. 
The eastern gable wall, as shown by the already preserved archival photographs from before the catastrophe, and before its dismantling immediately after the catastrophe, was made of solid brick on cement or lime-cement mortar, basically in a wagon system. The part of the stone wall that builds the rainbow arch visible above the vaults, on which the eastern gable wall of the nave was erected, was made of irregular stone, of various shapes and sizes. The rainbow arch itself, in the period preceding the disaster, was concentrated with metal elements. The gable wall was anchored from the west side to a wooden truss above the nave. The preserved, unimpaired roof truss above the presbytery, except for the part collapsed on the barrel vault, stiffens the gable wall from the east.

The vault above the nave was made as a barrel with six lunettes (Fig. 3). The cradle was stiffened with the buttresses visible from the dorsal vault. The vault with a thickness of $1 / 2$ brick, was made with bricks bonding with overlapping equal to half brick length. A hand-formed, dimensionally irregular brick was used for the construction. The guelter was made of solid brick with a thickness of approx. $25.5-27.0 \mathrm{~cm}$ and width from approx. 50 to approx. $80 \mathrm{~cm}$.

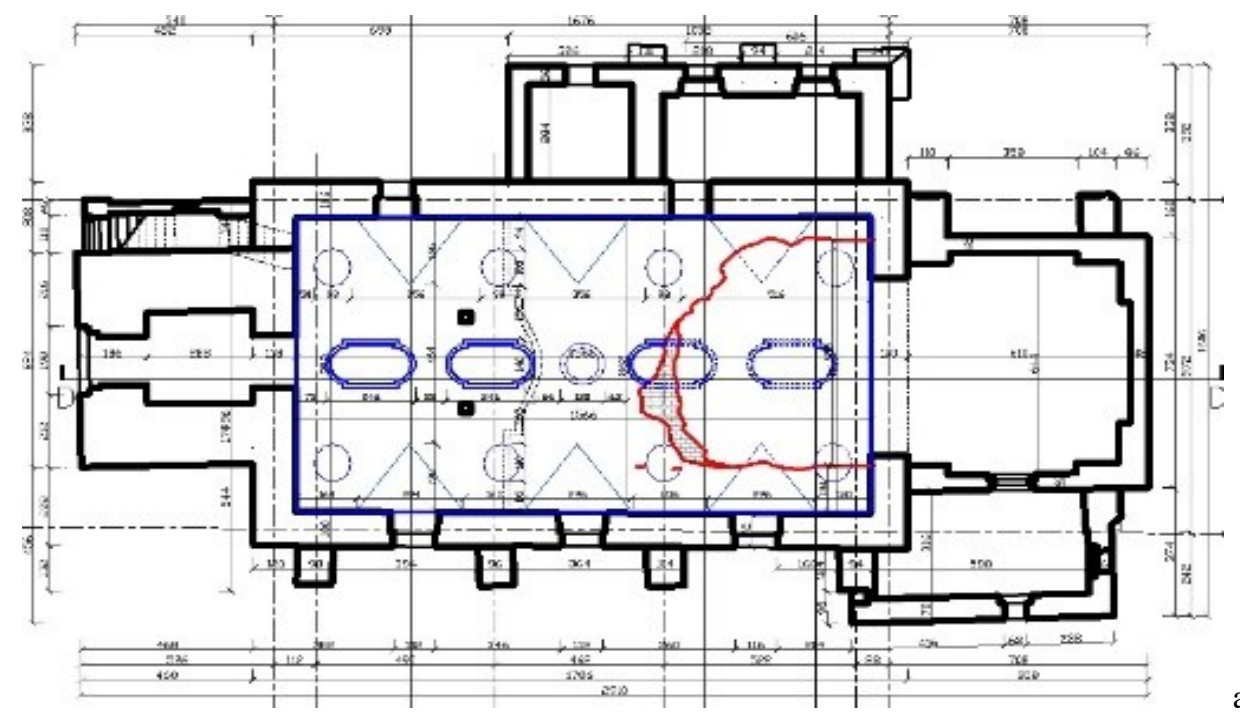

a)

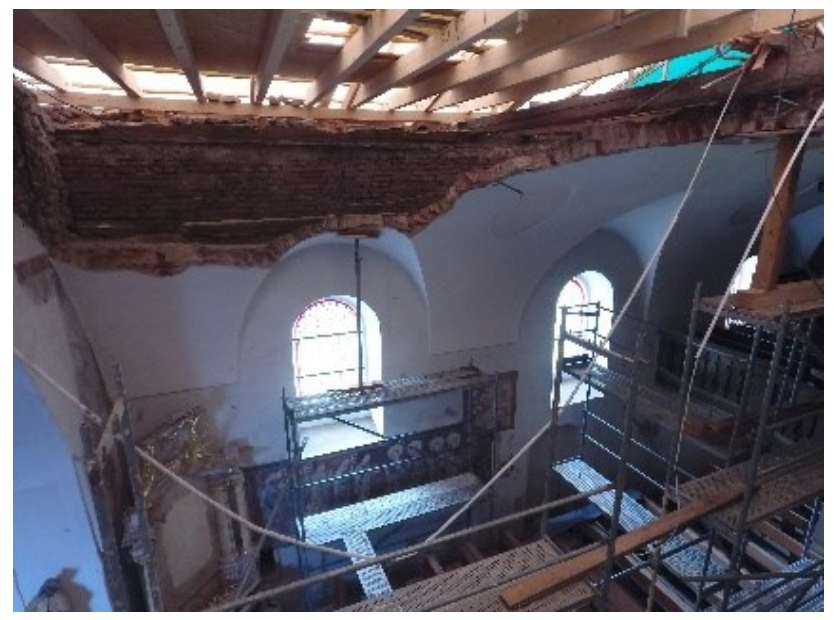

b)

Fig. 3. The barrel vault, a) plan, b) view after the disaster. 
The timber roof truss in the part above the nave was erected in the king post truss. The construction was probably made in the same period as the vault above the nave, that is at the turn of the seventeenth / eighteenth century. The construction material of the historical truss was unpolluted, hand-worked coniferous wood, supplemented to the present with other timber elements. The construction of the roof truss was connected with metal elements, both with the belfry wall and the top wall.

The roof of the church before the catastrophe was covered with a shiny, silver-gray steel sheet. Preserved numerous broken fragments of the natural maroon-gray slate, located in the tower and on the vaults, indicate the use of this material as well.

The presbytery, slightly lower and narrower than the nave, was built on a plan similar to a square, dimensions $6.62 \mathrm{~m}$ and $7.38 \div 7.46 \mathrm{~m}$. On the wall polychromy on the rainbow arch, there is a Romanesque church from the presbytery in the form of an apse, on the spot which the presbytery was built in its current form. The presbytery was covered with a cross vault. The present layout of the nave and presbytery is in line with the widespread "full schedule" in the Opole region in the early $13^{\text {th }}$ century [2]. The presbytery, in addition to local damages to the top wall of the eastern presbytery, caused by the failure of the lightning protection system, was not destroyed during a failure.

From the west to the nave there is a tower with a porch, through which leads the main entrance to the church. The tower was built on a square plan with dimensions $5.77 \times 6.05 \mathrm{~m}$. Stone stairs inside the tower lead to the choir, and erected above, from the height of $5.13 \mathrm{~m}$, the wooden structure carries a church bell, ceilings and ladder stairs. The stairs allow you to enter the top of the tower and the attic of the church. Thickness of the tower walls with each floor will decrease in size. The height of the tower from the level of the adjacent area is: to the crenellation $17.75 \mathrm{~m}$, and to the spade of the helmet $28.90 \mathrm{~m}$. The top of the tower was made in the form of crenellation, overlaid on arcades, which at the end of the nineteenth century was renovated or reconstructed in the spirit of neo-Gothic. The tower's helmet, finished with a metal ball and a cross with preserved gilding, was built in the form of a pyramid with a base on the plan of a quadrilateral. On the façades of the tower, the Romanesque biforia has been preserved, including the part under the roof of the main nave as un-plastered. On the east wall of the tower, anchor sockets with roof truss and metal protruding from it are readable, previously fastening one of the purlins of the roof truss.

On the elevation of the eastern tower there is an entrance portal with a bas-relief depicting St. George on a horse who smoothes a dragon. Bas-relief, along with the plates dismantled after 1945, commemorated those who belonged to the parish during World War I.

\section{Causes of a construction disaster}

On June 4, 2018 at about 8:00 am, during the construction works at the roof truss and covering the roof of the church, there was a construction disaster. The eastern top wall and about $1 / 4$ of the barrel vault area and a part of the wooden roof truss structure collapsed to the main nave of the church. Other structural elements of the object were also violated, including the unpolluted vault and external walls of the nave. As a result of the disaster, the elements of the church equipment were damaged. The most valuable element of the church, i.e. medieval polychrome, threatened with destruction.

According to the authors of the article, as in most construction disasters, the cause of the collapse of the gable wall, vaults and church roof truss was the accumulation of many causes, including long-term negligence, lack of periodic inspections and inspections, and a hasty decision to replace the whole roof truss over the main nave. 
To create a roof truss exchange design [3], on the basis of which construction works were carried out, no type and historical examination of the structural timber was carried out. It was proposed to replace the entire historic structure of the roof truss by designing cross-sections of elements (about three times smaller than the original) and a system of a construction layout that significantly deviates from the geometry of the original.

Among the negligence and design errors, also indicated in [4], should be mentioned:

- calculation errors of the roof truss structure - the permissible deflection values of the structure were exceeded, which could have caused pressure of the truss structure directly on the keystone cores,

- failure to perform:

- detailed measurement and drawing inventory of the historic object with details,

- comprehensive historical research and conservation research,

- ground geological research,

- lack of general conclusions and guidelines for restoration and architecture [5],

- lack of knowledge of the construction work in historical facilities, in which massive roof trusses ensure stability of the entire construction system - a newly designed truss, lighter than the original by about $2 / 3$, without the possibility of its anchoring, would be exposed at least, shifting and causing huge damage, including wall polychromy and possible health risk and people's lives!

In addition, design and implementation works were carried out without taking into account the provisions of preservation doctrines and legal regulations. The provisions of the Venice Charter for the Conservation and Restoration of Monuments and Sites [6] require:

- protection of the original substance of the monument, and taking up the restaurant should be undertaken only when necessary,

- ensuring the distinction between newly added elements and original batches.

So the disaster can be paradoxically treated as happiness before an even greater tragedy.

The direct cause of the crash was the wrong method of demolition of the roof truss and significant rainfall in the days preceding the disaster. Pulling one or both purlins westwards (towards the church tower) caused the collapse of the eastern gable wall, with which they were connected by metal elements.

It should also be mentioned that during the demolition work, proper supervision was lacking in the historical framework.

\section{The effects of a construction disaster}

Destruction or damage as a result of and after a construction disaster have resulted in:

1. The eastern gable wall of the nave closing the roof truss from the east - almost completely collapsed. The fragments remaining after collapsing, from about 40 to about $120 \mathrm{~cm}$ high, were dismantled. The preserved brick material coming from the gable wall was folded and protected against atmospheric influences next to the southern part of the church tower.

2. External walls. Transmitted vibrations caused partial stratification of walls, in particular in parts above vaults. Moreover, the collapse of the part of the barrel vault and damage to the rest of it could affect the overall stiffness of the whole object. Part of the damage to external walls, in particular in the area of the: coping, gable walls, arches and lintels, was also the result of destructive factors before failure. The course of the scratch may indicate the movement of the south-eastern part, according to the profiling of the area. The destruction of walls, including the emergence of new scratches and increasing existing ones, could have been influenced by:

- ground instability; 
- technology of building the church, including its stage implementation and numerous reconstructions and extensions over the centuries;

- high intensity of impact of aggressive factors resulting from the location, i.e. location almost directly at the municipal road; the vibrations generated by heavy farm vehicles passing at high speed near the church are particularly dangerous for the facility;

- precipitation causing moisture of the wall and penetration of harmful salt soluble in water and other impurities; improper water drainage from the upper parts of the wall led to major damage to the wall structure.

3. The vault above the nave in the part adjacent to the presbytery, along with the first buttress from the side of the presbytery, collapsed. In the middle field of the barrel vault, however, numerous scratches have been observed, which appeared after the construction disaster. During the local visions, in the first days after the disaster, before the development of technical expertise and monitoring of scratches, new cracks in the vault were noticed. The visible emergency places are the scratched vault areas in the longitudinal direction, in particular in the upper zone of the keystone and in the lunettes. The vault in this part has not been completely destroyed due to the assumed spines from the dorsal side. At the moment of the construction disaster, vibrations transferred to the vaults locally caused a loss of grip on the surfaces of the bricks in the vault. Some of the broken and welded joints became stuck. Removing the temporary vaulting of the vault may in the future, in particular during the course of repair work, reveal or also generate further damage to it.

4. Roof truss - after the construction disaster the contractor dismantled the roof truss almost completely, leaving only the bottom chords. The dismantled, cut roof truss was laid in the church area on two sides of the church, but it did not protect it from atmospheric influences and dampness from the ground. For the preserved elements of the damaged and dismantled roof truss after the construction disaster, documentation was prepared to serve the reconstruction after the construction disaster [7, 8].

Despite the fact that the contractor of construction works, under the supervision of the construction manager and inspector of construction supervision, he began to implement the securities, they were carried out in a hurry and chaotically. As part of preventive protection after the construction disaster, temporary protection of the vaults and the nave was carried out (Fig. 4 and Fig. 5). The vaults were secured with the use of building scaffoldings and elements of the undone roof truss. The wooden scaffold supports were based, among others on scaffolding platforms. In addition, the vault above the choir was supported by pillars in the axes of the ceiling of the choir. The ceiling of the choir was also stamped. The organs were protected against mechanical damage by chipboards.

Also, temporary works were carried out to secure the nave of the church, by installing a temporary wooden roof above it (Fig. 6). Tarpaulin covers were opened on the roof structure. The method of this construction was not consulted with the designer, conservation services and the Nysa District Construction Supervision Inspector. Also, it was not preceded by drawing and static and strength analysis. Provisional protection prevents or seriously limits access to the church part above the vaults and to the roof truss above the presbytery. It is also difficult to determine the impact of the protective structure on the safety of the structure. 


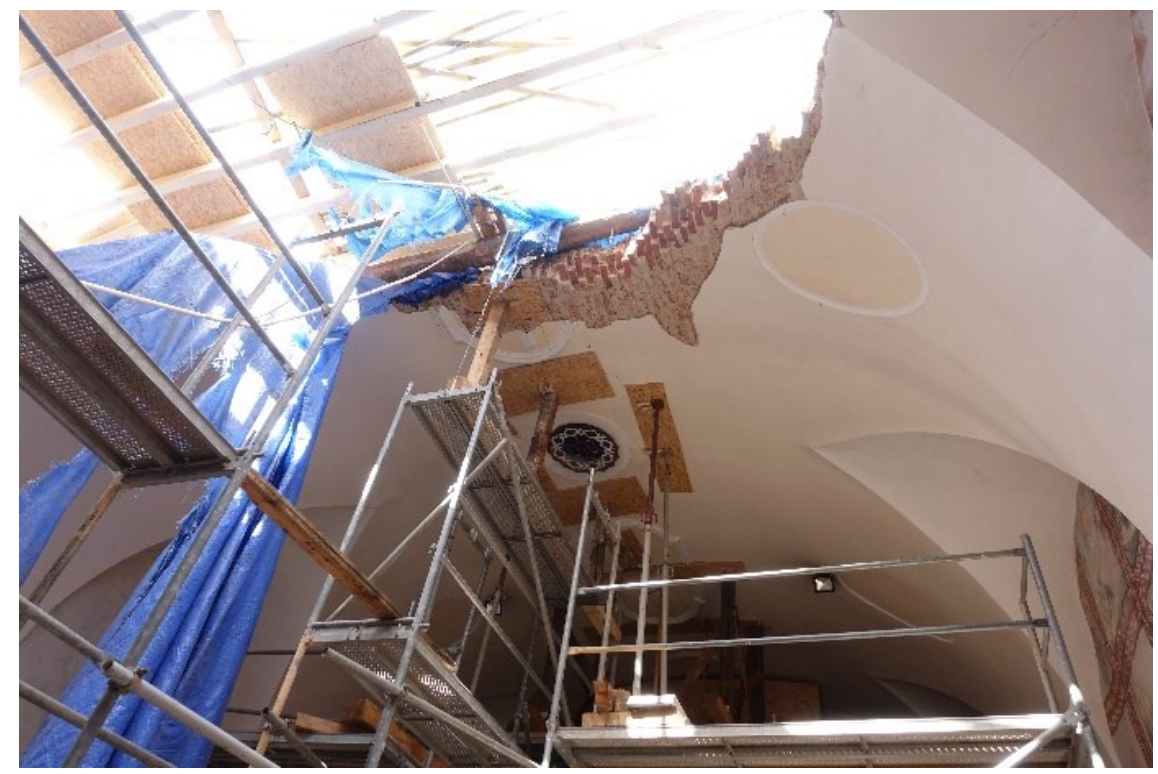

Fig. 4. Protection the vaults after the disaster.

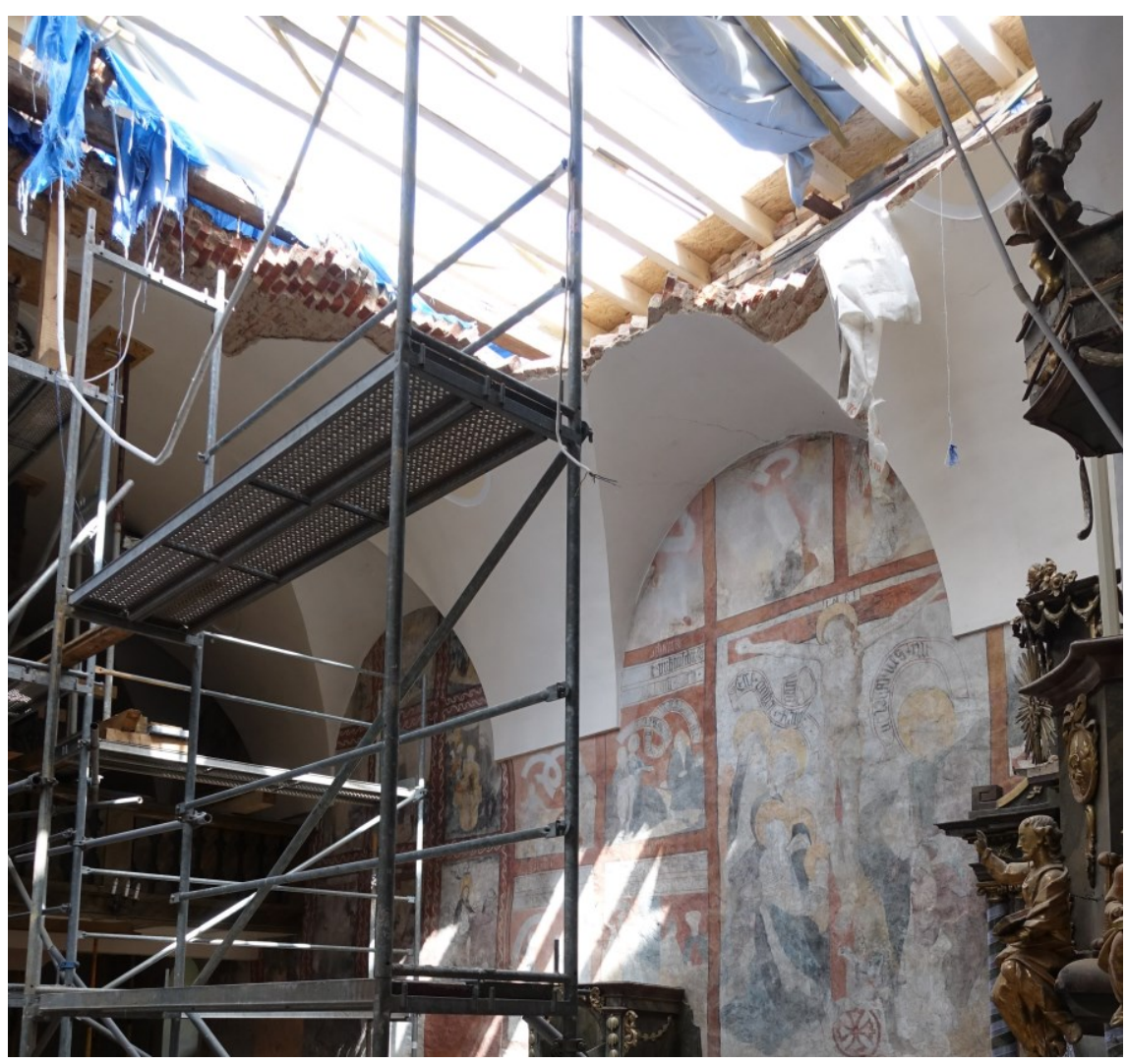

Fig. 5. Provisional protection of the vaults after a disaster. 

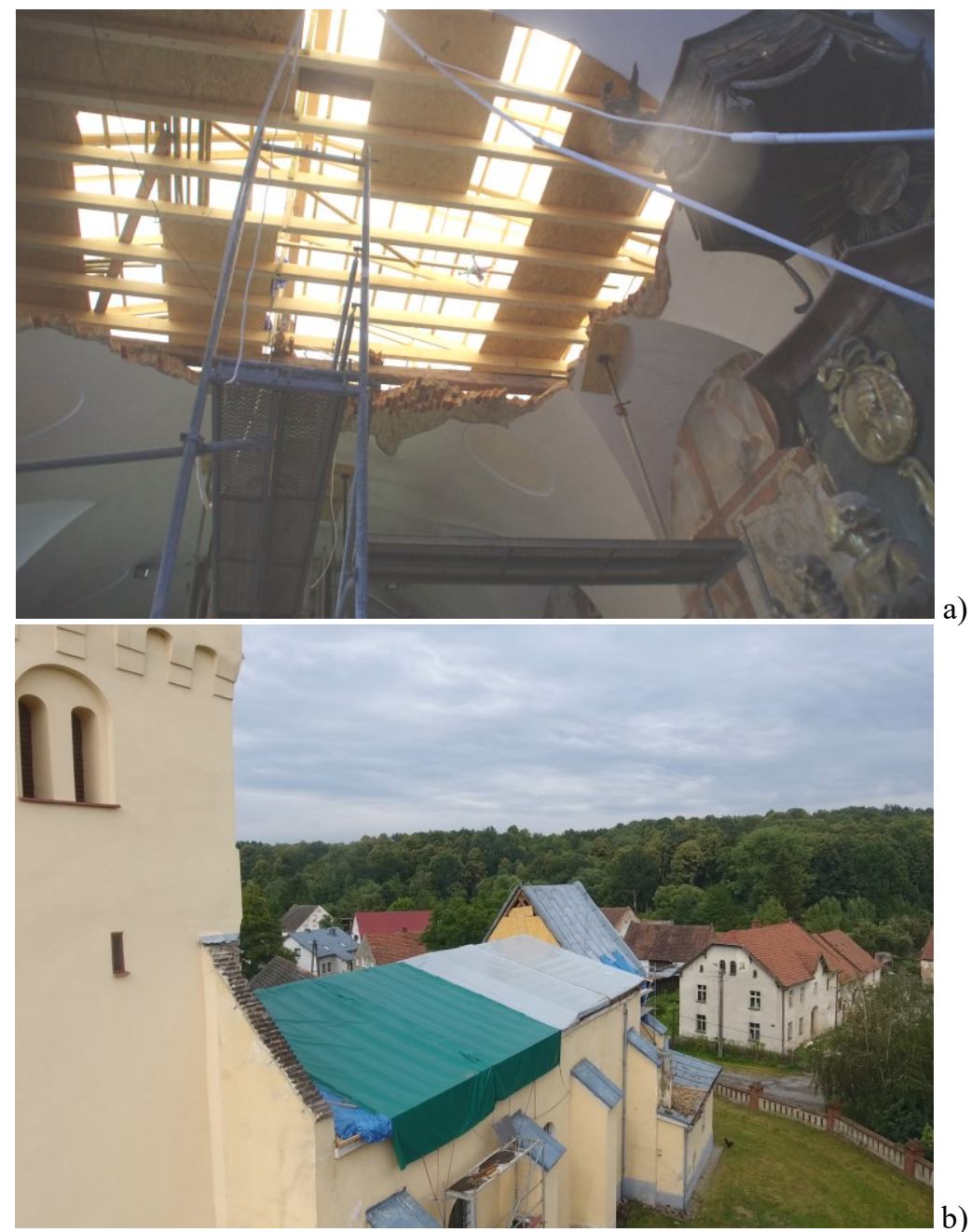

Fig. 6. Temporary timber roof above the nave of the church, a) view from the inside, b) view from the outside.

Moreover, the method and arrangement of the floor support will substantially reduce the use of the system scaffolding. The implementation problem will also be the removal of existing stamps and the establishment of a new scaffolding. Vault protection in the described form should be considered as inconsistent with engineering practice and as being likely, especially in winter, to threaten further collapsing of vaults and posing a threat to the health and life of people staying at the facility. The safeguards used do not have the character of static prophylaxis, aimed at partially or completely relieving the weakened structure of the object, including in particular supporting them and holding excessively cracked elements. 


\section{Repair work program}

The aim of construction and conservation activities in the facility is primarily to carry out treatments to preserve and protect the historic substance. The priority of conservation protection is to rebuild the permanent roof of the church as soon as possible, in order to effectively secure the valuable interior with the preserved $15^{\text {th }}$ century wall polychromes, as well as to restore the historical architecture and the church's shape. Work should first of all be carried out to protect the building against the risk of possible damage within the main nave.

Proposed conservation methods and selection of materials and technologies can be varied and individually matched to individual church elements. However, within the brick tissue the most desirable will be traditional technological and material solutions that will not violate the structural scheme of the monument. It is excluded to use structural elements that would be visible from outside the building or inside the nave and presbytery.

After carrying out comprehensive construction and conservation works, to the extent agreed with the conservation services, the aesthetic values of the object should be restored while stopping the destruction of the church and removal or significant reduction of the cause of damage and destruction.

\section{Summary}

For the disaster in the St. George church has made a number of factors. Apart from the above-mentioned direct causes, the problem of failure should be seen more widely, especially since it may refer to other historic sacred objects. Historical buildings are objects that do not meet the requirements of modern standards, and static and endurance analyzes are not directly applicable here. Among others, one should first of all mention the lack of knowledge and awareness of the importance of conservation issues expressing above all in:

- undertaking design and implementation works by entities that do not have sufficient knowledge and practice of working at monuments; in the study programs of building and architecture departments, the problems are marginalized (they can be provided eg by postgraduate studies in the field of maintenance, advanced analysis of historical constructions and repair and strengthening of such facilities),

- ignoring conservation doctrines,

- entrusting design and implementation works to entities offering the cheapest services (price criterion) - parishes are often the main and direct sponsors of the investment,

- omissions from periodic inspections.

Because knowledge about historical and modern materials and technologies (3D scanners, thermovision, flying drones, advanced techniques and calculation models, NDT, material analysis etc.) is usually out of the reach of entities undertaking design and implementation works, it is difficult to ensure durability of monuments in accordance with doctrines conservation. 


\section{References}

1. Online: https://opolskie.fotopolska.eu/1151058,foto.html?o=b23418, [access on:] January 2019

2. T. Chrzanowski, M. Kornecki, Catalog of art relics in Poland. / Tom VII, Opole Voivodeship. No. 9, Powiat Nyski (Państwowy Instytut Sztuki, Warszawa, 1963) [in Polish]

3. Design project: J. Murzyniak, Replacement construction project "Renovation of the roof structure of the St. Jerzy church in Hajduki Nyskie together with the exchange of roofing for flashings and guttering. A replacement project for the construction of a roof truss" (,BUDGRAF" Biuro Projektowo-Usługowe inż. Józef Murzyniak, Nysa 2018) [in Polish]

4. W. Baran, Technical Expertise: Condition of the St. George church in Hajduki Nyskie after the construction disaster on June 4, 2018 with the proposal of repair works (Opole, 2018) [in Polish]

5. J. Tachman, Standards in the design, implementation and supervision of conservation works related to architectural and construction monuments, (Narodowy Instytut Dziedzictwa, Torun-Warszawa, 2014) [in Polish]

6. The Venice Charter for the Conservation and Restoration of Monuments and Sites (1964)

7. P. Opałka, The program of construction and conservation works in the St. George church building in Hajduki Nyskie (Nysa, 2018) [in Polish]

8. P. Opałka, Ł. Bednarz, Construction project for the reconstruction of the St. Jerzy church in Hajduki Nyskie after a construction disaster (Nysa, 2018) [in Polish] 